\title{
Make or Buy: Offshoring of Services Functions in Manufacturing
}

\author{
Hildegunn Kyvik Nordås ${ }^{1,2}$ ()
}

Published online: 1 July 2020

(c) The Author(s) 2020

\begin{abstract}
About $40 \%$ of employment in manufacturing is in services functions. This paper develops a measure of narrow outsourcing: the matching of services functions that are performed by workers who are inside manufacturing firms to the same services functions that are provided by outside suppliers. Narrow outsourcing is entered into labour demand functions where labour is classified by business functions. The impact of narrow offshoring on manufacturing labour demand is small on average but depends strongly on the complexity of the value chain, the policy environment, and ICT maturity. The IT and R\&D functions are most sensitive to offshoring.
\end{abstract}

Keywords Labour demand · Offshoring · Outsourcing · Regulation · Structural changes $\cdot$ Technology

\section{JEL Classification F16}

\section{Introduction}

Between 25 and $60 \%$ of employment in manufacturing is in services functions such as transport, marketing, IT, R\&D, management, maintenance, repair, cleaning, and training (Miroudot and Cadestin 2017). Digitisation and trade liberalisation have significantly decreased transaction costs in services, which has opened the opportunity to outsource such supporting services. Following the rise of India as a major exporter of computer services, scholars took interest in the offshoring of services, which is sometimes referred to as "trade in tasks" (Grossman and Rossi-Hansberg 2008). Trade in tasks is portrayed as the latest turn in the spiral of ever-deepening specialisation and fragmentation of production.

Hildegunn Kyvik Nordås

Hildegunn@NUPI.no; Hildegunn.kyvik-Nordas@oru.se

1 Norwegian Institute of International Affairs (NUPI), Postboks 7024 St. Olavs Plass, 0130 Oslo, Norway

2 Örebro University, Örebro, Sweden 
According to business surveys in Europe and the Americas, however, firms tend to outsource services functions rather than individual tasks. ${ }^{1}$ Furthermore, the surveys reveal that most firms outsource locally. When they buy services from abroad, the source is most often countries in the same region with similar production costs as in their own country. Multinationals are more likely to offshore than are local firms, and the former often offshore from their own subsidiaries. The story of deepening globalisation through the slicing of the value chain into ever thinner slivers seems not to tally with the insights from these surveys.

This paper proposes an empirical approach to study the make-or-buy decision that is embedded in the offshoring literature in a multi-country setting. It exploits new information on employment in services within manufacturing firms and the 2016 release of the World Input Output Database (WIOD) to map the services functions that are produced inside the manufacturing sector and services that are provided by outside suppliers. I next use this mapping to create a new measure of narrow outsourcing and offshoring, which makes it possible to analyse rigorously the make-orbuy decision for services in the offshoring context in a similar manner as for goods.

The empirical literature on offshoring distinguishes between narrow and broad offshoring. The former includes imported intermediate inputs from the importing industry only, while broad offshoring comprises imports of any intermediate inputs. Broad offshoring captures all imports of intermediate inputs-not only inputs that are commonly produced in-house-and empirical offshoring studies therefore prefer to analyse narrow offshoring. From this perspective, offshoring of services is excluded. Given the importance of services functions inside manufacturing firms, however, narrow offshoring should capture not only the fabrication activities in manufacturing but also the supporting services functions.

Consider for example a computer engineer who is employed in the IT department of a car manufacturer. The market for her skills is IT departments in any sector, including special computer services firms. Similarly, she and her colleagues in the IT department face direct competition from computer services firms that may offer to take over the IT functions of the car manufacturer on a contractual basis rather than facing competition from car producers abroad.

The main contribution of this paper is, first, to create a measure of narrow offshoring that matches the services functions inside manufacturing to services that are provided by outside suppliers. Second, it analyses the relationship between market and product characteristics as well as the policy environment on the one hand and the outcome of the make-or-buy decision on the other. The contribution in this regard is to create sector-specific policy and technology indicators and explore how the location of services functions is conditioned on the policy and technology framework.

\footnotetext{
1 The National Organization Survey in the US and similar surveys in Canada and the European Union. See https://ec.europa.eu/eurostat/statistics-explained/index.php/International_sourcing_and_relocation _of_business_functions and http://irle.berkeley.edu/files/2013/The-2010-National-Organizations-Surve y.pdf.
} 


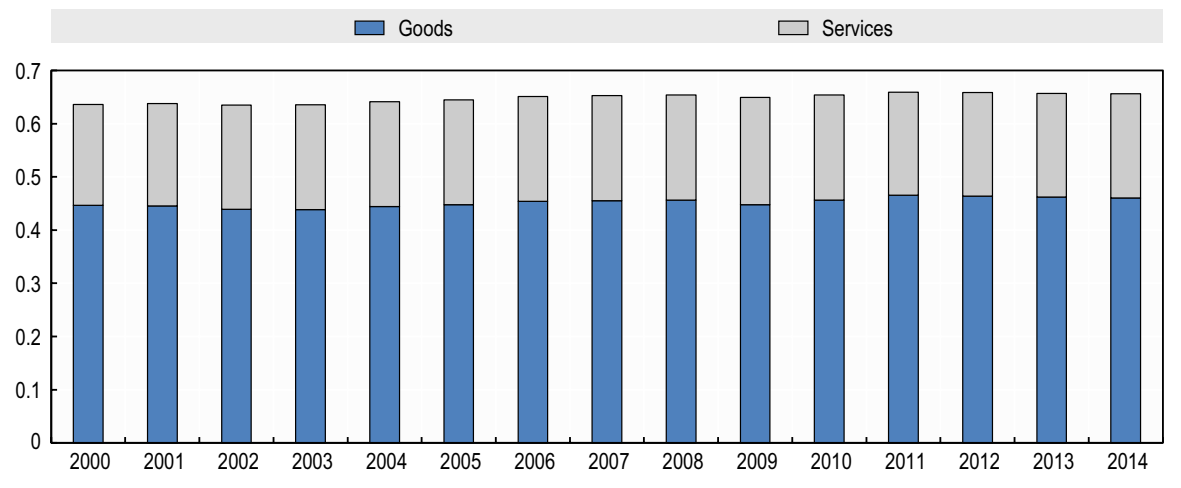

Fig. 1 Average share of intermediate goods and services in gross output. Source: Author's calculations based on WIOD; Miroudot and Cadestin (2017)

The data reveal that the aggregate share of services inputs in manufacturing has not changed much during the period 2000-2014. There is however substantial variation across manufacturing sectors and countries. Furthermore, the share that is offshored and the share that is produced inside manufacturing have both increased slightly at the expense of local services suppliers.

Tentatively, our results suggest that on average offshoring does not have a large impact on in-house employment. However, the average conceals large variations across sectors and functions. Furthermore, the marginal impact of offshoring on internal manufacturing employment strongly depends on the characteristics of the sector and the policy environment. Narrow offshoring affects manufacturing employment mainly in ICT-mature sectors. Narrow offshoring tends to replace inhouse functions in short and simple value chains, but narrow offshoring complements in-house functions in long and complex value chains. The function that is most affected by offshoring is R\&D, which seems to be completely hived off when offshored. Finally, narrow offshoring complements internal employment when policy barriers to entry and investment are high.

The rest of the study is organised as follows: The data and stylised facts are portrayed in Sect. 2. Section 3 positions the paper in the literature and describes the analytical framework. Regression results are presented and analysed in Sect. 4, while Sect. 5 concludes.

\section{Data and Stylised Facts}

\subsection{Data}

The main sources of data for this study are the 2016 release of the World Input Output Tables (WIOD), the associated Socio Economic Accounts (Timmer et al. 2015), and the OECD estimates of employment by business function (Miroudot and 


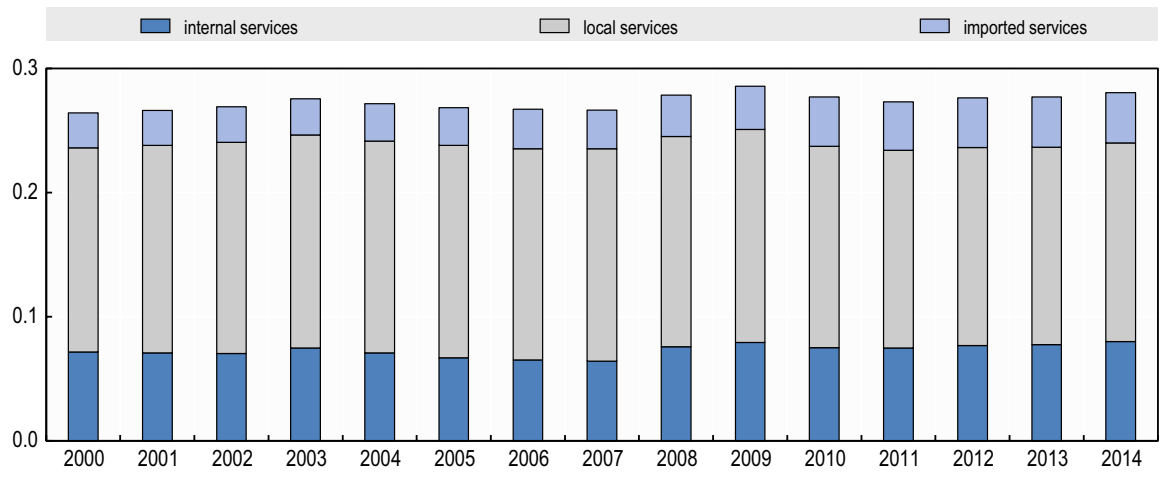

Fig. 2 Services inputs in manufacturing. Source: Author's calculations based on WIOD; Miroudot and Cadestin (2017)

Cadestin 2017). ${ }^{2}$ The WIOD input-output tables provide information on intermediate inputs by sector and source for 43 countries plus "rest of the world" from 2000 to 2014. Figure 1 depicts the average share of intermediate inputs in manufacturing for all of the countries that are included in the WIOD database by year. The most striking takeaway from this chart is the stability of the share of intermediate inputs: They account for about two-thirds of gross output throughout the period. Given the popular debate about the increasing fragmentation of production, this stability may be surprising. ${ }^{3}$ The share of intermediate services in gross output has also been stable: hovering around $20 \%$ and peaking at $21.1 \%$ in 2009 .

Services are also produced inside the manufacturing sector. Figure 2 classifies intermediate services inputs into locally sourced and imported and adds services that are produced internally. It shows that externally sourced services from the local market is the most important, followed by internal services production. Services that are imported directly account for a relatively small share. We also observe that although the overall share of services in gross output has been relatively stable over the past decade and a half, there has been a shift in the composition from locally sourced to internal and imported services. Thus, the import share of intermediate services has increased from 13 to $18 \%$ during the period 2000-2014.

The underwhelming dynamics that are gleaned from the averages conceal large differences across manufacturing sectors and across countries within the same sector. With respect to the variation across sectors, Fig. 3 shows the average services share of gross output by ISIC rev 4 manufacturing sector in 2014 for all WIOD countries. Sectors are ranked by the share of gross output that is provided by internal services functions. Unsurprisingly, the sector that uses services the most intensively is repair and installation of manufacturing equipment (C33); this is a sector that is at the borderline between goods and services. Manufacture of other transport

\footnotetext{
2 This section draws heavily on Nordås (2019).

${ }^{3}$ This may be partly, but far from entirely a statistical artefact since input-output coefficients may not be frequently updated in the underlying data.
} 


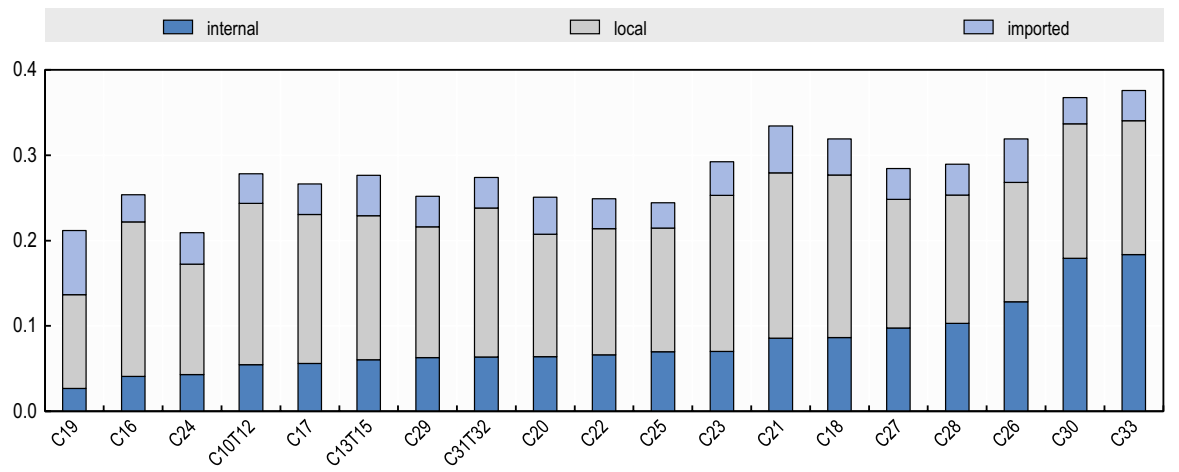

Fig. 3 Services inputs in manufacturing by sector, 2014. Source: Author's calculations based on WIOD; Miroudot and Cadestin (2017)

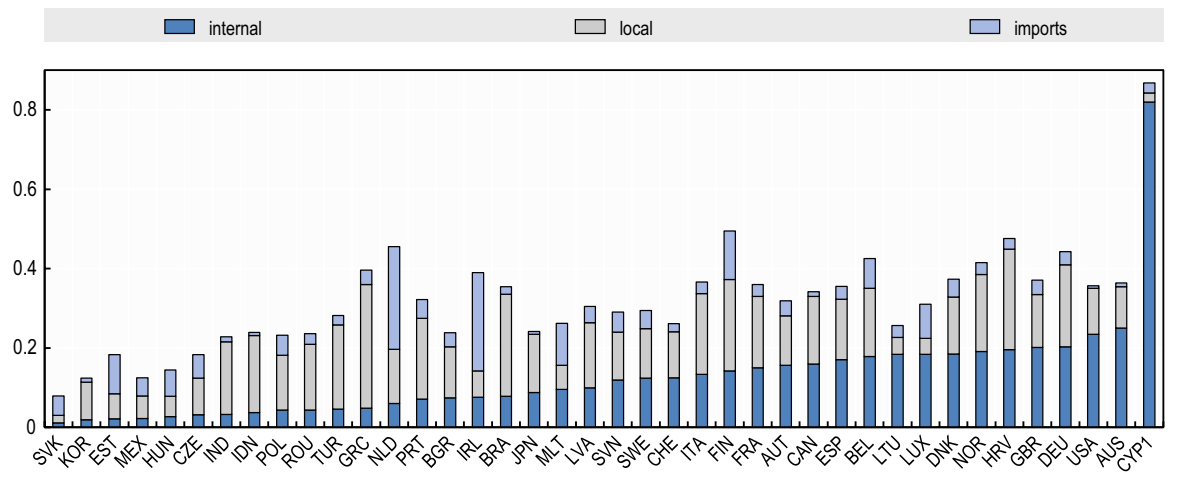

Fig. 4 Services inputs in manufacture of computer, electronic and optical products, 2014. Source: Author's calculations based on WIOD; Miroudot and Cadestin (2017)

equipment (C30) and pharmaceuticals (C21) follow as the second- and third-most services intensive manufacturing sectors. Pharmaceuticals have the highest share of locally outsourced services, while the highest share of imported services are found in the manufacture of coke and petroleum products (C19). ${ }^{4}$

Finally, we highlight differences in services intensity across countries. Such differences can be due to the variation in industrial structure across countries, or due to a more services-intensive production technology within a sector. Here we are interested in the latter, and choose the manufacture of computer, electronic, and optical products (C26) to illustrate the point. The sector is characterised by a large number of products that range from simple cables and switches to the most sophisticated computers and optical instruments. Internationally dispersed value chains in which there are large variations in the positioning of countries also distinguish it.

\footnotetext{
${ }^{4}$ We follow the practice in previous work and omit this sector from the econometric analysis in Sect. 4 due to measurement problems that are related to sharp fluctuations in oil prices (Foster-McGregor et al. 2016).
} 


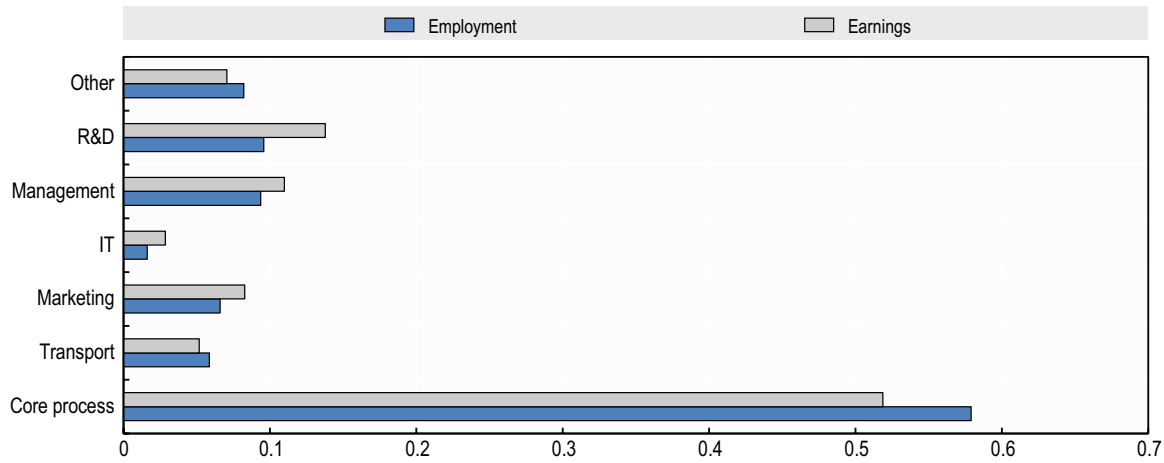

Fig. 5 Employment and earnings in manufacturing by business function, 2014. Source: Author's calculations based on WIOD; Miroudot and Cadestin (2017)

Figure 4 ranks countries by their intensity of internal services functions. It depicts substantial variation in both services intensities and the sourcing of services. At the one extreme, manufacturers in Cyprus appear to engage mainly in the services stages of the production process while in the Slovak Republic services account for less than $10 \%$ of gross output, of which more than half is imported.

To summarise the stylised facts: Services functions account for about $30 \%$ of manufacturing gross output and about $40 \%$ of employment in manufacturing. These aggregates have not changed much over time, but a slight shift from local outsourcing towards both imports and internal provision has been observed. Most importantly, there is substantial variation in both the services intensity and the sourcing of services across manufacturing industries and across countries within the same industry.

In the following sections we will exploit this variation to explain what determines whether services are made or bought in the manufacturing sector.

\subsection{Matching Internal Services Functions to Services Sectors}

Figure 5 exhibits the composition of employment by business function in manufacturing in 2014. On average almost $60 \%$ of employment and about half of wage earnings occur in the fabrication of products on the shop floor: the core processing function. Conversely, more than $40 \%$ of employment and half of the wage earnings go to services workers in the manufacturing sector. R\&D—which also includes engineering and other technical services-figures most prominently, followed by management/administration and marketing.

The next step is to match these services functions to the comparable sectors that are classified under the International Standards Industrial Classification (ISIC) rev 4 , which is used in the WIOD database. The matching is reported in Table 1 and reflects the description of the function in the business surveys, and the sector in the 


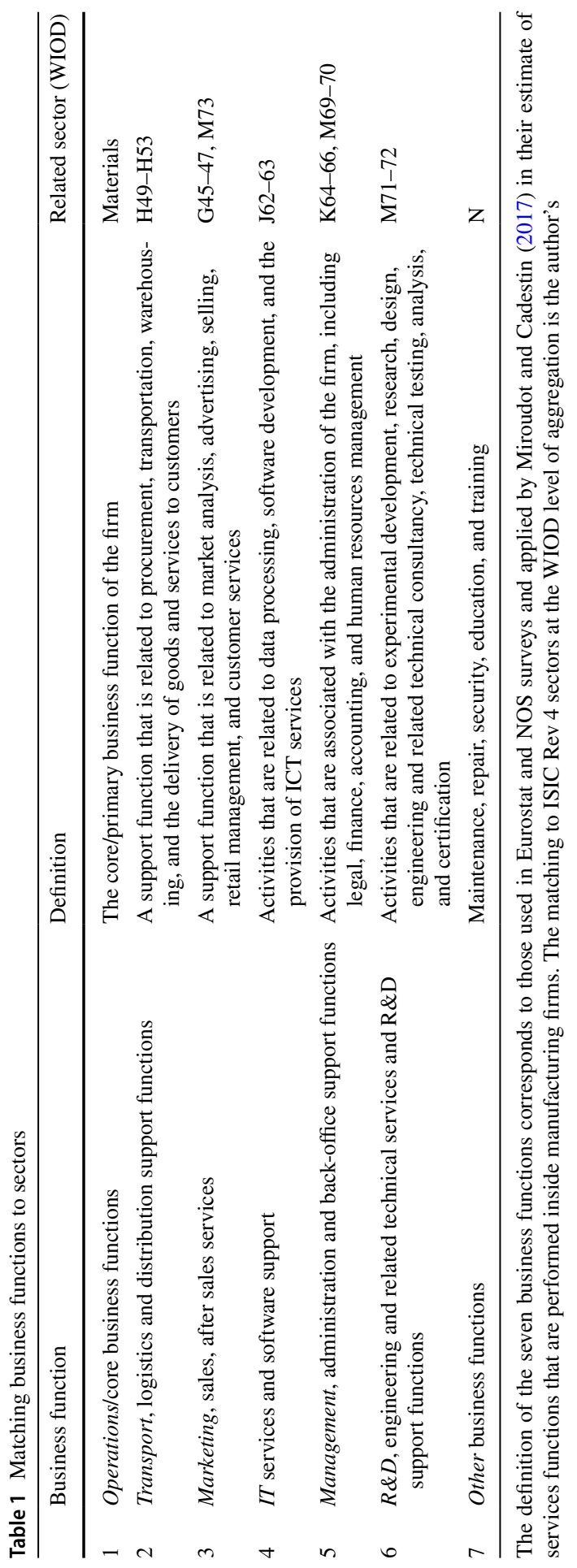




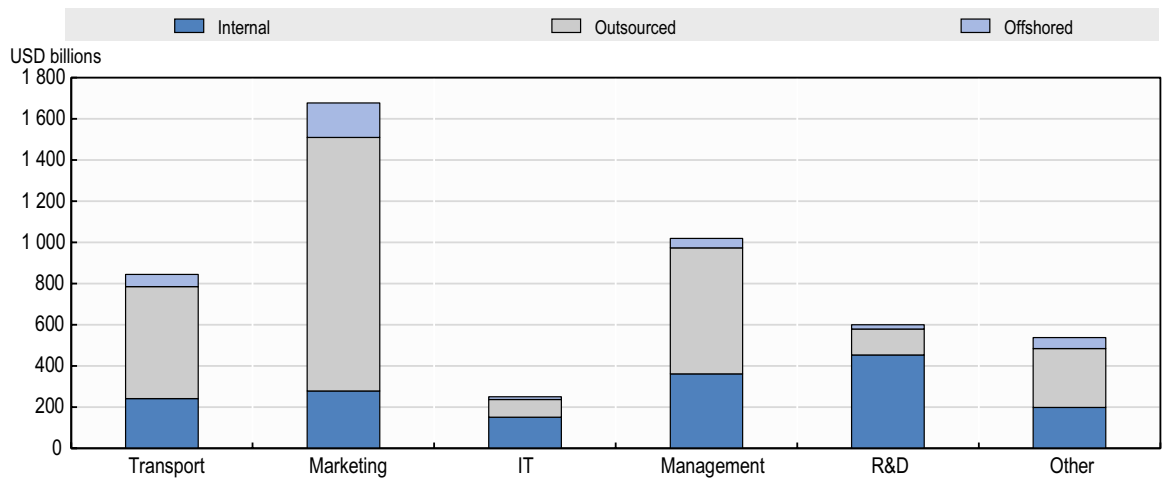

Fig. 6 Business functions by source. Source: Author's calculations based on WIOD; Miroudot and Cadestin (2017)

ISIC manual. ${ }^{5}$ The matching forms the basis for our measure of narrow offshoring, which is defined as the purchase from foreign suppliers of intermediate services that correspond to the in-house functions that are defined in Table 1 and illustrated in Fig. 6. Italics highlight the label that will be used for each function in the remainder of this paper.

The input from each service business function by source-internal, outsourced locally, or offshored-is depicted in Fig. 6. It adds up earnings by internal employees and payments to local and foreign suppliers for each function for total manufacturing in all of the countries that are covered. Consistent with Fig. 2-which reports totals for all service business functions-local outsourcing is also clearly the most important source of services for each function. There are, however, interesting differences across functions: Marketing and transport appear to be the functions that are most likely to be sourced from outside - and thus the furthest from the manufacturing core activity-while R\&D is the function that is most often provided inhouse. The IT function is surprisingly small and largely provided in-house. ${ }^{6}$ In the aggregate, offshoring does not feature prominently for any of the services business functions-although offshoring is important in some sectors and some countries.

\subsection{The Control Variables}

The relative cost of providing business functions in-house or sourcing them from outside suppliers depends on the characteristics of the sector as well as on the policy environment in which it operates. Sector characteristics and policy indices that are included in the empirical analysis are: the capital stock; price indices for

\footnotetext{
${ }^{5}$ Ideally one could explore sensitivity to the matching in the econometric analysis to follow. However, at the level of aggregation used in the WIOD table, there are no border sectors that could sensibly be matched with a different function.

${ }^{6}$ IT is a relatively new function, and IT departments may not be common in some industries. The number of observations is therefore fewer for these functions, as is reported in the descriptive statistics in Appendix Table 7.
} 
intermediate inputs; the length of the value chain; the level of ICT maturity; and the product market regulation index (PMR) from the OECD.

The capital stock as well as the price indices for intermediate inputs are provided in the WIOD Socio Economic Accounts. The capital stock is reported in millions of local currency in each country. To convert to US dollars, I calculated the capital to gross output ratio for each sector-country-year observation and multiplied these ratios with the corresponding gross output in the WIOD table where all variables are reported in US dollars. ${ }^{7}$ The price index for intermediate inputs aggregates all intermediate inputs and vary over time, across countries and sectors. The base year is 2010 .

The length of the value chain is defined as the number of production stages from raw material to final output. It has been calculated from the WIOD database with the use of a methodology that was developed by De Backer and Miroudot (2013) in a similar manner as calculating backward linkages.

Comparable policy indicators that cover the WIOD countries for the period 2000 to 2014 are not readily available. One of the few is the OECD Product Market Regulation (PMR) indicators. They are available for infrastructure-related serviceselectricity, gas, transport, post, and telecommunications-for the entire period for most of the countries that are included in the WIOD database. The PMR takes values between zero and six: Higher scores reflect more burdensome regulation. They cover information on entry barriers, public ownership, vertical integration, and market structure (Koske et al. 2015). A drawback for the purposes of this study is that the PMR varies across countries and over time, but not across manufacturing sectors, which makes identifying its impact difficult. Another problem is that the PMR combines information on policies and outcomes and may pose endogeneity problems when used in the regressions. ${ }^{8}$

We solve the first problem by creating sector-specific policy indices that exploit the sector variation in the intensity of use of infrastructure services within and across countries. We first calculate the weight of infrastructure services in each manufacturing sector in a benchmark country and year (the United States for 2000) based on the WIOD input-output tables and then multiply the sector-specific weights with the country-year specific PMR index to obtain a country-year-sector specific policy measure. The second problem is mitigated by using the entry regulation sub-indicator, which does not contain outcome measures (see Appendix Table 8 for details).

The ICT-maturity indicators are from the OECD (Calvino et al. 2018) and characterise sectors by their investment in tangible ICT and software and the share of on-line sales in total sales. The indicators are available at the ISIC rev4 2-digit level and can be matched directly with the WIOD sectors. However, ICT maturity does not vary over time or across countries. See the descriptive statistics in Appendix Table 7.

\footnotetext{
7 This methodology avoids measurement errors due to fluctuating exchange rates.

8 The outcome measures that are included in the PMR for network services are the number of firms that operate in the market and the market share of new entrants.
} 


\section{The Analytical Framework}

Previous studies that relate offshoring to changes in overall employment found no or limited effects (Hijzen et al. 2011; Liu and Trefler 2008). Nevertheless, there is evidence of quite significant effects on the skills composition of employment and relative wages (Geishecker and Görgy 2013; Hijzen et al. 2005). ${ }^{9}$ Little is known about the impact of offshoring on the functional composition of employment, but there is some evidence that offshoring of material inputs from the US to China is associated with a net decline in low-skilled production workers, which has been more-thanoffset by a net increase in employment of non-production workers (Wright 2014).

Analysis of micro data is suitable for gaining insights on job creation and job separation across firms within sectors and sometimes even within firms, which can allow distinguishing between firm and worker characteristics. It is, however, difficult to study trade and regulatory policy drivers of labour market outcomes in countryspecific microanalysis, since firms and workers within a country face the same policy environment. Furthermore, it is well known from the classical work of Hecksher, Ohlin, Vanek, and others that trade leads to changes in relative prices, which drive a reallocation of resources to their most efficient use. These changes affect all firms and workers in the economy-not only those who are directly engaged in trade. Therefore, cross-country analysis may be more suitable for policy analysis and studies on the overall impact of trade.

The WIOD and the TiVA databases have been instrumental for cross-country analysis of trade and jobs at the industry level. They confirm that overall employment is mostly determined by factors other than trade and trade policy. There is evidence that services offshoring has contributed to making hiring and firing more sensitive to changes in wages and other market conditions (Foster-McGregor et al. 2013; Hijzen and Swaim 2010), and thus may have had an impact on job security. ${ }^{10}$ Finally, cross-country analyses support the finding that offshoring may have contributed to the polarisation of earnings: where the medium-skilled workers have seen their share of the total wage bill decline to the benefit of high-skilled workers andto a less extent- - to low-skilled workers (Foster-McGregor et al. 2016).

\subsection{Theoretical Framework}

The fundamental question that determines the relationship between local outsourcing, offshoring and the internal provision of business functions is firms' make-orbuy decisions. This question has been central to the field of economics since its inception with the work of Adam Smith in the eighteenth century. The classical work looked at the question from a growth and development perspective. Growing industries create space for deeper specialisation that allows firms to hive off noncore activities to outside suppliers. In the process, firms become more productive,

\footnotetext{
9 These studies analyse UK micro data.

10 The studies find that offshoring is associated with higher labour demand elasticities.
} 
and new sectors emerge from taking up the hived-off functions. Thus, what is noncore activities for one firm becomes the core of another as the size of the market expands and sustains more extensive specialisation (Stigler 1951). ${ }^{11}$

The transaction cost approach to the study of organisations considers transactions as the basic unit of analysis and transaction costs as a key determinant of the boundary of the firm (Williamson 1981). An early empirical analysis of the make-or-buy decision in automobile manufacturing hypothesised that firms are more likely to make inputs: when demand for the final output is uncertain; when there is uncertainty related to technology, including design of the component in question; when the manufacturer has a cost advantage in producing the input; or when there is little competition in the upstream supplier market. In addition, the experience of both the buyer and the seller matters (Walker and Weber 1984).

The cost of governing outside suppliers also depends on the characteristics of the product and the production process. Complex processes beget complex contracts that may be difficult to draw up and monitor-which raises the relative transaction cost of outsourcing (Tadelis 2002; Bashir and Thomson 1999; Novak and Eppinger 2001). The cost of outsourcing includes not only the contractual payments to the outside suppliers and the cost of governing the contract, but also the cost of re-integrating the outsourced process into production.

The concept of modularity is useful for understanding the relative costs of makeversus-buy from a business perspective. Modularity is defined as the portioning of a process or a product into independent and self- contained modules. Modular processes are more likely to be outsourced than are non-modular processes, and business functions that can be fine-sliced into individual tasks are associated with a lower cost of reintegration into the production process of the outsourcing firm (Elia et al. 2017). ${ }^{12}$

The literature on offshoring embeds the make-or-buy decision into a trade model with intermediate inputs that can be made in-house, sourced from local suppliers, or sourced from abroad (Antràs and Helpman 2004). There are four possible outcomes of the make-or-buy decision: (1) make at home; (2) make in a subsidiary that is established abroad; (3) buy from a local supplier; or (4) buy from a foreign supplier. Each outcome is associated with a set of fixed and variable costs, and the decision should aim to minimise the total production and transaction costs. Setting up a subsidiary abroad is the highest fixed-cost alternative, but the higher cost of establishment may be compensated by lower cost of operations. The cost of governing production is lower when performed inside the firm, but lack of scale may still favour outside suppliers. In addition, compliance costs with foreign regulation as well as outright trade and investment barriers add to the costs of engaging in offshoring.

The underlying analytical framework for the empirical analysis in this paper is a standard model of outsourcing with differentiated products, monopolistic

\footnotetext{
11 In contrast, declining industries tend to integrate vertically-as for instance has been observed by Porter (1979).

12 The authors argue that firms should focus on making business functions more modular to reap the benefit from offshoring to third parties.
} 
competition, and heterogeneous firms that is inspired by Melitz (2003) and Antràs and Helpman (2004). Firms differ along the productivity dimension, and firms of higher productivity can absorb the higher fixed costs of sourcing from outside suppliers-whether the suppliers are local or foreign. We make the standard assumption that the fixed cost of offshoring is higher than the fixed cost of outsourcing to local suppliers, which in turn is higher than making the input in-house. Variable governance and transaction costs would typically follow the same pattern, while the cost of the input would often be highest when produced in-house and cheapest when offshored. Firms will offshore if their productivity level is such that revenue net of variable costs covers the fixed cost of offshoring.

Standard offshoring models assume that firms are heterogeneous along the productivity dimension and that firms' productivity follows a Pareto distribution. This is justified empirically and has the convenient property that all possible outcomes of the make-or-buy decision can be observed in the same country, same industry at the same time. Changes in the relative fixed and variable cost of offshoring will affect the productivity threshold of the different outcomes, and thus the number of firms that produce in-house, outsource locally or offshore. The offshoring response to changes in trade costs can therefore be analysed with the use of data at the sector level-for instance, the WIOD database.

\subsection{Empirical Strategy}

The demand for workers who perform each business function (V) is derived from maximizing profits subject to input prices and short-run capacity constraints. I follow Hijzen and Swaim (2010) in estimating unconditional labour demand where capital enters the regression as a quasi-fixed input. This capital-constrained model positions the labour demand curve in the factor price space and in addition captures scale effects. In accordance with the literature, outsourcing and offshoring enter the equation as shift parameters, which means that for a given level of input prices and capital, outsourcing and offshoring may shift labour demand up or down, but do not affect the elasticity of labour demand with respect to factor prices.

Demand for workers who perform function $f$ in sector $i$, country $c$ at time $t$ can be written as follows:

$$
\ln V_{f i c, t}=\alpha_{0}+\sum_{f=1}^{F} \alpha_{f} w_{f i c, t}+\delta_{f} O u t_{f i c, t}+\theta_{f} O f f_{f i c, t}+\beta_{f} \ln k_{i c, t}+\sum_{l} \gamma_{l, f} z_{l, i c, t}
$$

The first term is a constant, while the second term contains the average wage rate of workers who perform each of the seven business functions in Table 1. The next two terms represent narrow local outsourcing and offshoring intensity, respectively. ${ }^{13}$ Narrow offshoring is defined as in Table 1 which matches business functions performed in-house to intermediate input sectors from the WIOD tables. They

\footnotetext{
13 Following Hijzen and Swaim (2010), outsourcing and offshoring intensity is calculated as locally sourced and imported intermediate inputs respectively as share of value added in the sector.
} 
are function, sector, country, and time specific; and as noted they enter as shift parameters. The fifth term denotes the capital stock, which is country and sectorspecific, but does not vary across business functions, although the elasticity of labour demand with respect to capital may vary across business functions. The last term represents a set of control variables that also serve as labour demand shifters: a price index for intermediate inputs; the length of the value chain; ICT maturity; and the PMR.

A price index for intermediate inputs is included as an aggregate measure of the cost of sourcing inputs from external suppliers. If intermediate inputs on average are substitutes to in-house labour, the coefficient on the price index would take a positive sign. The length of the value chain is included to capture the complexity of production, which should tilt the make-or-buy decision towards make. The ICT revolution has instigated the standardisation, digitisation, and sometimes automation of a number of services tasks, which makes them more offshorable. ICT maturity is introduced to capture this effect, and we expect that it would contribute to more offshoring. Finally, the policy environment affects the relative cost of making or buying. The PMR indices for infrastructure-related services reflect burdensome regulation that make services markets less competitive, and we expect them to favour in-house production.

Labour demand functions are estimated in 5-year differences to reduce the sensitivity to measurement error as follows ${ }^{14}$ :

$$
\Delta l n l_{f i c, t}=\alpha_{0}+\sum_{f=1}^{F} \alpha_{f} \Delta \ln w_{f i c, t}+\delta_{f} \Delta O u t_{f i c, t}+\theta_{f} \Delta O f f_{f i c, t}+\beta_{f} \Delta \ln k_{i c, t}+\sum_{l} \gamma_{l f} \Delta l n z_{l i c, t}+\varepsilon_{c i f, t}
$$

As noted, outsourcing, offshoring, and the controls that are included in the second-to-last term in the regression equation are entered as shift parameters additively. However, it may well be the case that the elasticity of labour demand with respect to offshoring depends on the policy and technology environment. For instance, industries that use ICT intensively may be more sensitive to offshoring than are less ICT intensive industries. To capture this possibility, I also run a set of regressions where narrow offshoring is interacted with the control shifters. These regressions are estimated in levels with country, year and industry fixed effects to control for unobserved country, sector or time-specific factors that could influence labour demand. ${ }^{15}$

\section{Results}

I start with the estimation of capital-constrained unconditional aggregate labour demand while introducing services outsourcing and offshoring as shift parameters. This very basic regression is to confirm that the WIOD 2016 version exhibits the predicted relationship between employment and the core variables in the

\footnotetext{
14 Before taking logs, variables are truncated by one in order to capture observations with zero value.

15 This is necessary since interaction terms are not compatible with difference equations.
} 
Table 2 Labour demand $(\Delta)$ by business function and broad outsourcing and offshoring, manufacturing

\begin{tabular}{|c|c|c|c|c|c|c|c|}
\hline & $\mathrm{F} 1$ & $\mathrm{~F} 2$ & F3 & F4 & F5 & F6 & F7 \\
\hline $\begin{array}{l}\Delta \text { ln wage } \\
1\end{array}$ & $\begin{array}{l}-0.205^{* * * *} \\
(0.030)\end{array}$ & $\begin{array}{l}0.158 * * * \\
(0.048)\end{array}$ & $\begin{array}{l}0.068 \\
(0.059)\end{array}$ & $\begin{array}{l}-0.002 \\
(0.057)\end{array}$ & $\begin{array}{l}-0.234 * * * \\
(0.048)\end{array}$ & $\begin{array}{l}-0.247 * * * \\
(0.053)\end{array}$ & $\begin{array}{l}-0.045 \\
(0.051)\end{array}$ \\
\hline $\begin{array}{l}\Delta \text { ln wage } \\
2\end{array}$ & $\begin{array}{l}-0.044^{* *} \\
(0.022)\end{array}$ & $\begin{array}{l}-0.403 * * * \\
(0.035)\end{array}$ & $\begin{array}{l}-0.119 * * * \\
(0.042)\end{array}$ & $\begin{array}{l}-0.029 \\
(0.041)\end{array}$ & $\begin{array}{l}-0.027 \\
(0.035)\end{array}$ & $\begin{array}{l}-0.015 \\
(0.038)\end{array}$ & $\begin{array}{l}0.046 \\
(0.037)\end{array}$ \\
\hline $\begin{array}{l}\Delta \text { ln wage } \\
3\end{array}$ & $\begin{array}{l}-0.018 * \\
(0.011)\end{array}$ & $\begin{array}{l}-0.035^{* *} \\
(0.017)\end{array}$ & $\begin{array}{l}-0.209 * * * \\
(0.021)\end{array}$ & $\begin{array}{l}0.039 * \\
(0.020)\end{array}$ & $\begin{array}{l}0.074 * * * \\
(0.017)\end{array}$ & $\begin{array}{l}0.036 * \\
(0.019)\end{array}$ & $\begin{array}{l}-0.026 \\
(0.018)\end{array}$ \\
\hline $\begin{array}{l}\Delta \text { ln wage } \\
4\end{array}$ & $\begin{array}{l}0.017 \\
(0.011)\end{array}$ & $\begin{array}{l}0.007 \\
(0.018)\end{array}$ & $\begin{array}{l}-0.027 \\
(0.022)\end{array}$ & $\begin{array}{l}-0.326^{* * * *} \\
(0.021)\end{array}$ & $\begin{array}{l}-0.025 \\
(0.018)\end{array}$ & $\begin{array}{l}0.007 \\
(0.020)\end{array}$ & $\begin{array}{l}0.011 \\
(0.019)\end{array}$ \\
\hline$\Delta$ ln wage & $\begin{array}{l}-0.127 * * * \\
(0.017)\end{array}$ & $\begin{array}{l}-0.056^{* *} \\
(0.028)\end{array}$ & $\begin{array}{l}0.071 * * \\
(0.034)\end{array}$ & $\begin{array}{l}0.071 * * \\
(0.033)\end{array}$ & $\begin{array}{l}-0.037 \\
(0.028)\end{array}$ & $\begin{array}{l}0.032 \\
(0.031)\end{array}$ & $\begin{array}{l}-0.088 * * * \\
(0.030)\end{array}$ \\
\hline $\begin{array}{l}\Delta \text { ln wage } \\
6\end{array}$ & $\begin{array}{l}-0.054 * * * \\
(0.010)\end{array}$ & $\begin{array}{l}-0.069 * * * \\
(0.016)\end{array}$ & $\begin{array}{l}-0.060 * * * \\
(0.020)\end{array}$ & $\begin{array}{l}-0.041^{* *} \\
(0.019)\end{array}$ & $\begin{array}{l}-0.142 * * * \\
(0.016)\end{array}$ & $\begin{array}{l}-0.378^{* * * *} \\
(0.018)\end{array}$ & $\begin{array}{l}0.071 * * * \\
(0.017)\end{array}$ \\
\hline $\begin{array}{l}\Delta \text { ln wage } \\
7\end{array}$ & $\begin{array}{l}0.068 * * * \\
(0.018)\end{array}$ & $\begin{array}{l}0.091 * * * \\
(0.029)\end{array}$ & $\begin{array}{l}-0.088^{* *} \\
(0.035)\end{array}$ & $\begin{array}{l}0.010 \\
(0.034)\end{array}$ & $\begin{array}{l}0.033 \\
(0.028)\end{array}$ & $\begin{array}{l}-0.028 \\
(0.031)\end{array}$ & $\begin{array}{l}-0.233^{* * *} \\
(0.030)\end{array}$ \\
\hline $\begin{array}{c}\Delta \text { ln price } \\
\text { interme- } \\
\text { diates }\end{array}$ & $\begin{array}{l}-0.056^{* *} \\
(0.022)\end{array}$ & $\begin{array}{l}-0.077^{* *} \\
(0.035)\end{array}$ & $\begin{array}{l}-0.235^{* * *} \\
(0.042)\end{array}$ & $\begin{array}{l}0.036 \\
(0.041)\end{array}$ & $\begin{array}{l}-0.052 \\
(0.035)\end{array}$ & $\begin{array}{l}-0.103 * * * \\
(0.038)\end{array}$ & $\begin{array}{l}0.270 * * * \\
(0.037)\end{array}$ \\
\hline$\Delta \ln$ capital & $\begin{array}{l}0.418 * * * \\
(0.015)\end{array}$ & $\begin{array}{l}0.265 * * * \\
(0.023)\end{array}$ & $\begin{array}{l}0.155^{* * * *} \\
(0.028)\end{array}$ & $\begin{array}{l}0.223 * * * \\
(0.028)\end{array}$ & $\begin{array}{l}0.370^{* * * *} \\
(0.023)\end{array}$ & $\begin{array}{l}0.417 * * * \\
(0.026)\end{array}$ & $\begin{array}{l}0.229 * * * \\
(0.025)\end{array}$ \\
\hline $\begin{array}{c}\Delta \text { ln out- } \\
\text { sourcing } \\
\text { (broad) }\end{array}$ & $\begin{array}{l}-0.034^{* *} \\
(0.017)\end{array}$ & $\begin{array}{l}-0.003 \\
(0.027)\end{array}$ & $\begin{array}{l}-0.078^{* *} \\
(0.032)\end{array}$ & $\begin{array}{l}-0.021 \\
(0.032)\end{array}$ & $\begin{array}{l}0.045^{*} \\
(0.027)\end{array}$ & $\begin{array}{l}0.169 * * * \\
(0.029)\end{array}$ & $\begin{array}{l}0.052 * \\
(0.028)\end{array}$ \\
\hline $\begin{array}{c}\Delta \ln \text { off- } \\
\text { shoring } \\
\text { (broad) }\end{array}$ & $\begin{array}{l}0.034 * * \\
(0.013)\end{array}$ & $\begin{array}{l}-0.013 \\
(0.022)\end{array}$ & $\begin{array}{l}0.018 \\
(0.026)\end{array}$ & $\begin{array}{l}-0.033 \\
(0.026)\end{array}$ & $\begin{array}{l}0.074 * * * \\
(0.022)\end{array}$ & $\begin{array}{l}-0.164 * * * \\
(0.024)\end{array}$ & $\begin{array}{l}-0.061 * * * \\
(0.023)\end{array}$ \\
\hline $\mathrm{R}^{2}$ & 0.230 & 0.085 & 0.085 & 0.092 & 0.114 & 0.223 & 0.084 \\
\hline $\mathrm{N}$ & 3386 & 3386 & 3386 & 3386 & 3386 & 3386 & 3386 \\
\hline
\end{tabular}

Five-year difference regressions. Robust standard errors are reported in parentheses and ***, **, and * represent statistical significance at $1 \%, 5 \%$, and $10 \%$ level, respectively. The dependent variable is labour demand by function measured in total hours worked, and wages are hourly wages by function. Column headings correspond to the function as numbered in Table 1

labour demand function. The result is reported in Appendix Table 9. As expected: Labour demand is downward sloping in wages; investment generates employment; higher prices of intermediate inputs tilt the make-or-buy decision towards make; local outsourcing of services supports employment in manufacturing; while the offshoring of services does not have a statistically significant impact on overall manufacturing employment.

I next classify employment into the seven functions that were presented in Table 1 and run the same regressions for each function, using seemingly unrelated regressions (SUR) where all variables are in 5-year differences, and I use the broad measures of outsourcing and offshoring. Table 2 reports the results. 
The own- and cross-price elasticity of labour demand by function reveals complementarities and substitutability among business functions. First, and reassuringly, all own-price elasticities are negative, and all are statistically significant, except for the management function. The core operations function is complementary to management and R\&D (negative cross price elasticity) and a substitute for transport (positive cross-price elasticity). These results are intuitively appealing as the number of managers and supervisors tend to follow the number of shop-floor workers. It also makes sense that higher wages for shop-floor workers is associated with more R\&D, which in turn is likely to be associated with higher productivity when targeting process innovation or higher output prices when targeting product innovation. Finally, one could envisage that higher wages for core operators may raise the demand for transport workers. This occurs if (e.g.) machine operators initially do some internal transport. A wage rise could then trigger the transfer of internal transport to a specialised transport division. Presumably internal transport workers are less skilled and earn lower wages than do machine operators.

Marketing substitutes for management and $R \& D$. The latter may suggest that firms have two ways of product differentiation: product development, or targeting certain market segments through marketing. R\&D complements all other business functions except "other".

We note that, as in the aggregate, outsourcing to local suppliers goes hand-inhand with higher labour demand for management, R\&D and "other" functions, but is negatively associated with labour demand in core operations and marketing. Offshoring on the other hand is associated with higher employment in core operations and the management function, and less employment in the R\&D and "other" functions. Thus, we note that outsourcing and offshoring core operations, R\&D and "other" have opposite effects on in-house labour demand. This is further discussed below.

With respect to narrow offshoring, labour demand in each of the seven business functions is regressed on matched local- and foreign-sourced services as indicated in Table 1. The results are reported in Table 3. The impact of narrow outsourcing and offshoring is strikingly different from broad outsourcing and offshoring. Fewer functions are affected, but the marginal impact of those concerned is larger.

Only marketing and R\&D are significantly related to outsourcing, while offshoring is significantly associated with core processing, R\&D, and "other" functions. Interestingly, the marginal impact is quite strong for R\&D—with opposite signs for outsourcing and offshoring. Recall, however that R\&D is mainly done in-house (see Fig. 6), so that a small change in absolute numbers will translate into a large percentage change.

Remarkably, while outsourced R\&D increases labour demand in in-house R\&D, offshored R\&D has the opposite effect with a similar but less precisely estimated parameter in absolute value. A possible story behind these results is that $\mathrm{R} \& \mathrm{D}$ - particularly the research part of it-requires a minimum efficient scale and highly specialised skills. Only large and innovative companies can recover the cost of research. Smaller and less innovative companies resort to licensing technology, which tends to be an arms-length transaction. The development part of R\&D in contrast often involves in-house teams that are supported by external 
Table 3 Labour demand $(\Delta)$ by business function, narrow outsourcing and offshoring, manufacturing

\begin{tabular}{|c|c|c|c|c|c|c|c|}
\hline & $\mathrm{F} 1$ & $\mathrm{~F} 2$ & F3 & F4 & F5 & F6 & F7 \\
\hline $\begin{array}{c}\Delta \text { ln wage } \\
1\end{array}$ & $\begin{array}{l}-0.209 * * * \\
(0.030)\end{array}$ & $\begin{array}{l}0.157 * * \\
(0.048)\end{array}$ & $\begin{array}{l}0.066 \\
(0.059)\end{array}$ & $\begin{array}{l}-0.003 \\
(0.057)\end{array}$ & $\begin{array}{l}-0.225 * * * \\
(0.048)\end{array}$ & $\begin{array}{l}-0.260 * * * \\
(0.053)\end{array}$ & $\begin{array}{l}-0.046 \\
(0.051)\end{array}$ \\
\hline $\begin{array}{l}\Delta \text { ln wage } \\
2\end{array}$ & $\begin{array}{l}-0.048^{*} \\
(0.022)\end{array}$ & $\begin{array}{l}-0.402 * * * \\
(0.035)\end{array}$ & $\begin{array}{l}-0.116^{* *} \\
(0.042)\end{array}$ & $\begin{array}{l}-0.028 \\
(0.041)\end{array}$ & $\begin{array}{l}-0.030 \\
(0.035)\end{array}$ & $\begin{array}{l}-0.001 \\
(0.038)\end{array}$ & $\begin{array}{l}0.051 \\
(0.037)\end{array}$ \\
\hline $\begin{array}{l}\Delta \text { ln wage } \\
3\end{array}$ & $\begin{array}{l}-0.021 * \\
(0.010)\end{array}$ & $\begin{array}{l}-0.034^{*} \\
(0.017)\end{array}$ & $\begin{array}{l}-0.208^{* * * *} \\
(0.021)\end{array}$ & $\begin{array}{l}0.041 * \\
(0.020)\end{array}$ & $\begin{array}{l}0.071 * * * \\
(0.017)\end{array}$ & $\begin{array}{l}0.053 * * \\
(0.019)\end{array}$ & $\begin{array}{l}-0.019 \\
(0.018)\end{array}$ \\
\hline $\begin{array}{l}\Delta \text { ln wage } \\
4\end{array}$ & $\begin{array}{l}0.018 \\
(0.011)\end{array}$ & $\begin{array}{l}0.006 \\
(0.018)\end{array}$ & $\begin{array}{l}-0.027 \\
(0.022)\end{array}$ & $\begin{array}{l}-0.329 * * * \\
(0.021)\end{array}$ & $\begin{array}{l}-0.020 \\
(0.018)\end{array}$ & $\begin{array}{l}-0.002 \\
(0.020)\end{array}$ & $\begin{array}{l}0.009 \\
(0.019)\end{array}$ \\
\hline$\Delta_{5} \ln$ wage & $\begin{array}{l}-0.125 * * * \\
(0.017)\end{array}$ & $\begin{array}{l}-0.056^{*} \\
(0.028)\end{array}$ & $\begin{array}{l}0.071 * \\
(0.034)\end{array}$ & $\begin{array}{l}0.070 * \\
(0.033)\end{array}$ & $\begin{array}{l}-0.039 \\
(0.028)\end{array}$ & $\begin{array}{l}0.042 \\
(0.031)\end{array}$ & $\begin{array}{l}-0.092^{* *} \\
(0.030)\end{array}$ \\
\hline $\begin{array}{l}\Delta \ln \text { wage } \\
6\end{array}$ & $\begin{array}{l}-0.052 * * * \\
(0.010)\end{array}$ & $\begin{array}{l}-0.069 * * * \\
(0.016)\end{array}$ & $\begin{array}{l}-0.061^{* *} \\
(0.020)\end{array}$ & $\begin{array}{l}-0.042 * \\
(0.019)\end{array}$ & $\begin{array}{l}-0.142^{* * * *} \\
(0.016)\end{array}$ & $\begin{array}{l}-0.383^{* * *} \\
(0.018)\end{array}$ & $\begin{array}{l}0.070 * * * \\
(0.017)\end{array}$ \\
\hline $\begin{array}{l}\Delta \text { ln wage } \\
7\end{array}$ & $\begin{array}{l}0.070 * * * \\
(0.018)\end{array}$ & $\begin{array}{l}0.091 * * \\
(0.029)\end{array}$ & $\begin{array}{l}-0.089 * * \\
(0.035)\end{array}$ & $\begin{array}{l}0.005 \\
(0.034)\end{array}$ & $\begin{array}{l}0.044 \\
(0.028)\end{array}$ & $\begin{array}{l}-0.046 \\
(0.031)\end{array}$ & $\begin{array}{l}-0.237^{* * *} \\
(0.030)\end{array}$ \\
\hline $\begin{array}{c}\Delta \ln \text { price } \\
\text { interme- } \\
\text { diates }\end{array}$ & $\begin{array}{l}-0.059 * * \\
(0.022)\end{array}$ & $\begin{array}{l}-0.075^{*} \\
(0.035)\end{array}$ & $\begin{array}{l}-0.234 * * * \\
(0.042)\end{array}$ & $\begin{array}{l}0.037 \\
(0.041)\end{array}$ & $\begin{array}{l}-0.060 \\
(0.035)\end{array}$ & $\begin{array}{l}-0.077^{*} \\
(0.038)\end{array}$ & $\begin{array}{l}0.285 * * * \\
(0.037)\end{array}$ \\
\hline $\begin{array}{l}\Delta \ln \\
\quad \text { capital }\end{array}$ & $\begin{array}{l}0.412 * * * \\
(0.014)\end{array}$ & $\begin{array}{l}0.266^{* * * *} \\
(0.023)\end{array}$ & $\begin{array}{l}0.159 * * * \\
(0.028)\end{array}$ & $\begin{array}{l}0.238 * * * \\
(0.027)\end{array}$ & $\begin{array}{l}0.351 * * * \\
(0.023)\end{array}$ & $\begin{array}{l}0.449 * * * \\
(0.025)\end{array}$ & $\begin{array}{l}0.246 * * * \\
(0.024)\end{array}$ \\
\hline $\begin{array}{r}\Delta \text { ln out- } \\
\text { sourcing } \\
\text { (narrow) }\end{array}$ & $\begin{array}{l}-0.040 \\
(0.034)\end{array}$ & $\begin{array}{l}-0.126 \\
(0.219)\end{array}$ & $\begin{array}{l}-0.363^{* *} \\
(0.126)\end{array}$ & $\begin{array}{l}0.100 \\
(1.226)\end{array}$ & $\begin{array}{l}-0.222 \\
(0.269)\end{array}$ & $\begin{array}{l}1.720 * * * \\
(0.313)\end{array}$ & $\begin{array}{l}0.057 \\
(0.413)\end{array}$ \\
\hline $\begin{array}{c}\Delta \text { ln off- } \\
\text { shoring } \\
\text { (narrow) }\end{array}$ & $\begin{array}{l}0.151 * * * \\
(0.035)\end{array}$ & $\begin{array}{l}-0.088 \\
(0.501)\end{array}$ & $\begin{array}{l}0.178 \\
(0.306)\end{array}$ & $\begin{array}{l}5.291 \\
(2.897)\end{array}$ & $\begin{array}{l}0.268 \\
(0.751)\end{array}$ & $\begin{array}{l}-2.233^{*} \\
(0.949)\end{array}$ & $\begin{array}{l}0.405 * \\
(0.200)\end{array}$ \\
\hline $\mathrm{R}^{2}$ & 0.232 & 0.085 & 0.085 & 0.092 & 0.109 & 0.215 & 0.083 \\
\hline $\mathrm{N}$ & 3386 & 3386 & 3386 & 3386 & 3386 & 3386 & 3386 \\
\hline
\end{tabular}

Five-year difference regressions. Robust standard errors are reported in parentheses and ***, **, and * represent statistical significance at $1 \%, 5 \%$, and $10 \%$ level, respectively. The dependent variable is labour demand by function measured in total hours worked, and wages are hourly wages by function

services providers who work close to the operation activities. Frequent face-toface interaction is needed in this kind of activity, which is therefore more likely to be sourced locally. Furthermore, such collaboration requires substantial in-house capacity to make full use of external support (Bengtsson and Dabhilkar 2009; Muller and Zenker 2001).

The analytical framework that explains the make-or-buy decision emphasises the nature of the product and production process as important determinants. As noted, complex production processes and products beget complex contractual relationships. Complex contractual relationships in turn may require more in-house effort to monitor and enforce the contracts. We use the length of the value chain as an indicator of complexity and analyse to what extent it makes a difference with respect to the inhouse employment response to outsourcing and offshoring. 
Table 4 Marginal effect of offshoring on labour demand by business function

\begin{tabular}{|c|c|c|c|c|c|c|}
\hline \multicolumn{7}{|l|}{ Conditioned on length of value chain } \\
\hline Length of value chain & $\mathrm{F} 1$ & $\mathrm{~F} 2$ & F3 & $\mathrm{F} 4$ & F5 & F6 \\
\hline Mean less 0.5 standard deviations & -0.21 & -3.94 & -2.55 & 18.41 & -6.79 & 2.96 \\
\hline Mean & -0.08 & -2.50 & -1.51 & 12.66 & -4.08 & 1.20 \\
\hline Mean plus 0.5 standard deviations & 0.05 & -1.06 & -0.46 & 6.91 & -1.36 & -0.56 \\
\hline Mean plus one standard deviation & 0.18 & 0.38 & 0.58 & 1.15 & 1.36 & -2.32 \\
\hline
\end{tabular}

The table reports the marginal effect of offshoring on internal employment in each services business function inside manufacturing for coefficients that are significantly different from zero

Thus, do offshored services function require more in-house support and monitoring in long value chains? Or conversely, are business functions more likely to be completely hived off in long value chains? We explore this question by entering the length of the value chain together with an interaction term with offshoring in the labour demand system.

A potential problem is that outsourcing, and offshoring may result in longer value chains, which could constitute an endogeneity problem. The length of the value chain and offshoring are indeed correlated but except for the core operations function, the correlation is weak (see Appendix Table 10). If the length of the value chain is partly determined by offshoring, the estimate of the marginal effect of offshoring conditioned on the length of the value chain would be upward-biased. The marginal impact of offshoring on in-house labour demand by function at different lengths of the value chains are reported in Table 4, while the full regression results are presented in Appendix Table 11.

Bearing in mind the caveat that the estimates could be upward-biased, we first notice that the marginal impact on labour demand in manufacturing is statistically significant for all business functions except "other". There are also fundamental differences among the six remaining business functions. Operations, transport, marketing, and management depict a similar pattern, while the IT and the R\&D functions display different and distinct features.

With respect to transport, marketing, and management, the result indicates that when value chains are short and simple, offshoring is associated with a large reduction in in-house employment in the same function. Within our analytical framework of heterogeneous firms, the result suggests that the firms that offshore these business functions completely hive them off-possibly retaining an internal interface with foreign suppliers. With increasing complexity, however, the marginal impact of offshoring on in-house employment in the same function turns positive, which supports the prediction that complex processes require more in-house support. In addition, the finding is consistent with dynamic offshoring and automation models where tasks 
Table 5 Marginal labour demand effect of narrow offshoring by ICT intensity

\begin{tabular}{llrlclll}
\hline ICT maturity & F1 & F2 & F3 & F4 & F5 & \multicolumn{1}{l}{ F6 } & F7 \\
\hline High & -0.003 & -1.244 & -0.055 & -7.656 & 2.958 & $-10.464 * * *$ & $-3.688^{* *}$ \\
Medium & -0.015 & -0.340 & -0.014 & $5.704^{*}$ & 0.445 & -1.361 & $0.408^{*}$ \\
Low & $-0.309^{* * *}$ & 0.195 & -0.676 & 6.098 & -0.389 & 13.903 & 0.575 \\
\hline
\end{tabular}

The table reports the coefficients on the log of narrow offshoring when the labour demand regressions by function are estimated for each ICT maturity category separately, using 5-year difference regressions. $* * *, * *$, and * represent statistical significance at $1 \%, 5 \%$ and $10 \%$, level, respectively. The dependent variable is labour demand by function measured in total hours worked, and wages are hourly wages by function. The numbers of observations are 832, 2132, and 422 for High, Medium, and Low, respectively

and functions are standardised, digitised, and offshored or automated, while in-house workers move on to new functions that cannot easily be offshored or automated. ${ }^{16}$

IT and R\&D follow a different pattern. As was shown in Figs. 5 and 6, IT is by far the smallest services function in manufacturing, and there are fewer observations for this function than for the other six. There may therefore be more noise in the data for this function than the others. With this caveat in mind, it appears that narrow offshoring of IT functions is strongly complementary to in-house employment when supply chains are short and simple. With lengthening value chains, the positive effect on inhouse employment declines sharply. Similar to the business functions that were discussed above, this finding is also consistent with a dynamic offshoring model where mature tasks and functions are automated and offshored while new tasks and functions are performed in-house. For IT functions the job creation effect is stronger than the destruction effect in short value chains, while the balance shifts towards the job destruction effect as the value chain becomes longer and more complex.

Finally, the offshoring of R\&D is complementary to in-house employment when supply chains are short but turns negative when they get longer and more complex. Furthermore, offshoring replaces internal $R \& D$ functions with a higher marginal effect the longer the value chain. As was discussed above, R\&D may not be modular. It is therefore less likely to be offshored; but when it is, the entire function may be offshored. This may particularly refer to research, where external sourcing is often in the form of arms-length licensing.

Another important factor that characterises the product and production process is technology - particularly ICT. Most studies find that ICT is skills-biased: It pushes up the demand and relative wages for skilled workers. This paper explores a different aspect: whether ICT affects the sensitivity of labour demand to offshoring. For this I use the OECD ICT maturity index: It is sector-specific but unfortunately does not vary across countries and over time. The best I can do to study the different marginal effects conditioned on ICT maturity is to divide manufacturing into different ICT maturity categories and run the labour demand regressions separately for each category.

I sort manufacturing industries into three categories: high, medium and low ICT maturity and run the same SUR regressions that were reported in Table 3 for each

16 See for instance Acemoglu and Restrepo (2018) for a recent model that focuses on automation. 
Table 6 Marginal effect of offshoring on labour demand by business function

\begin{tabular}{llllll}
\hline \multicolumn{6}{l}{ Conditioned on regulatory burden (PMR) } \\
\hline & F1 & F2 & F3 & F5 & F7 \\
\hline $\begin{array}{l}\text { Mean less 0.5 } \\
\text { standard } \\
\text { deviation }\end{array}$ & 0.18 & 0.07 & 0.94 & 2.18 & 0.53 \\
$\begin{array}{l}\text { Mean } \\
\begin{array}{l}\text { Mean plus } \\
\text { 0.5 standard } \\
\text { deviations }\end{array}\end{array}$ & 0.70 & 7.71 & -0.85 & 2.18 & 2.01 \\
\end{tabular}

The table reports the marginal effect of offshoring on internal employment in each business function for coefficients that are significantly different from zero as reported in Appendix Table 12

category. High ICT maturity is defined as sectors with an ICT maturity index that is greater than one standard deviation above the mean; low ICT maturity refers to a score that is more than one standard deviation below the mean; and medium ICT maturity represent the scores between high and low ICT maturity. ${ }^{17}$

Table 5 reports the results. In the interest of space, I report the coefficients on narrow offshoring only.

We recall that narrow offshoring is significantly related to labour demand only for core operations, R\&D, and "other" in the pooled regressions for all manufacturing sectors. When I split the sample into the three categories, the same functions are significantly affected by offshoring, but it appears that the results are largely driven by the high ICT maturity sectors. In this category, R\&D offshoring has a particularly large and negative impact on labour demand for the in-house R\&D function. There is also a relatively large impact on "other" in the high ICT maturity category. For core operations, in contrast, only low ICT maturity sectors are affected by narrow offshoring. We finally note that there is a large but not very precisely estimated impact of offshoring of IT functions in medium ICT mature sectors.

With respect to the relative cost of the different outcomes of the make-or-buy decision, trade and investment restrictions as well as burdensome domestic regulation are important determinants of such costs. Unfortunately, information on the fixed and variable costs that are related to the four outcomes of the make-or-buy decision is not available. As was discussed in the data section, the only relevant policy indicator that covers the sectors, countries, and years that correspond to the WIOD data is the OECD PMR indicators, which capture the regulatory burdens that face the key services inputs to manufacturing.

In the same manner as for the length of the value chain, the PMR and an interaction term between the PMR and offshoring are introduced into the regressions to explore whether the marginal effect of offshoring on the internal provision of services functions varies with the level of regulation.

\footnotetext{
${ }^{17}$ Low ICT maturity sectors are: basic metals (C24); and fabricated metals (C25). High-ICT maturity sectors are: food, beverages, and tobacco (C10 to $\mathrm{C} 12)$; machinery (C28); motor vehicles (C29); and other transport equipment (C30). Medium ICT maturity captures the rest.
} 
The marginal effects are reported in Table 6 , and the full regressions are in Appendix Table 12.

Product market regulation is significantly associated with offshoring and employment in core operations, transport, marketing, management and "other". With respect to the core operations function, offshoring complements in-house employment, which is consistent with the results that were reported in Table 3. Furthermore, the marginal impact is stronger when the regulation is more burdensome. A similar pattern is observed in the transport function: Since transport is location-specific, offshoring of the transport function must be related to exports of final output and imports of intermediate inputs. ${ }^{18}$ More research is needed on the interface between own-account transport and transport that is sourced from external providers in an international trade context to explain this result.

The offshoring of marketing supports internal employment when the regulatory burden is low but replaces in-house marketing functions when the regulatory burden is high. One can only speculate what might explain this finding: A possibility is that modern marketing is highly information-intensive, is subject to substantial scale economies, and relies heavily on efficient logistics, distribution, and telecommunications inputs. With a high regulatory burden falling on these inputs, they are likely to be expensive, and only large and highly productive manufacturers have sufficient scale to benefit from doing marketing themselves. Furthermore, the interface between offshored and in-house marketing may become more distinct and marketing may become more arms-length with weaker infrastructure services. ${ }^{19}$

In-house administration complements offshored administration when product market regulation is considered, although the marginal effect is independent on the level of regulation. Finally, "other" follows a similar pattern as core operations: Offshoring the "other" function is associated with more complementary in-house employment the more burdensome is regulation.

\section{Concluding Remarks}

This study has analysed the employment impact of offshoring and outsourcing services functions from manufacturing: I match the services functions that are performed inside manufacturing to services that are sourced from outside. Previous studies have defined narrow offshoring as imports of materials from the same sector, which ignores the fact that services workers inside manufacturing are also exposed to the offshoring of the activities that they perform. Given that on average about $40 \%$ of employment in manufacturing is in services functions-with a slightly increasing trend over time-shedding light on the relationship between services workers and service offshoring in manufacturing is important.

\footnotetext{
18 The offshoring of transport services is indeed correlated with the exports of final output and imports of intermediate goods, with significant correlation coefficients of 0.5 and 0.6 , respectively.

19 Previous work shows that a higher regulatory burden is associated with weaker performance in the regulated sector (Nordås and Rouzet 2017).
} 
As is true of previous studies I find that offshoring has a relatively small impact on overall labour demand in manufacturing. However, the average conceals large differences across functions. The function that is most sensitive to offshoring is clearly R\&D: Offshoring replaces in-house employment irrespective of the characteristics of the sector or policy environment. It is, however, worth noticing that offshoring accounts for a very small share of expenditure on $\mathrm{R} \& \mathrm{D}$, and the relatively large marginal effects are from a small base. The IT function is also highly sensitive to narrow offshoring, but in this case offshoring complements and strengthens in-house employment.

As is predicted by trade and industrial organisation theory, the labour demand response to offshoring depends on sector characteristics as well as the policy environment in which manufacturing operates. Complexity - as captured by the length of the value chain-is the most important factor that shapes labour demand dynamics in manufacturing. Apart from R\&D, in-house employment is less sensitive to offshoring when the value chain is longer. Furthermore, apart from R\&D, narrow offshoring is associated with lower in-house employment in short value chains, but as the value chain lengthens, the effect turns positive and narrow offshoring strengthens in-house employment in long value chains. It appears, however, that the employment effect of services offshoring is largely confined to high ICT maturity sectors.

To conclude, the employment impact of narrow offshoring of services functions in manufacturing is small on average but with substantial differences across business functions and when conditioned on technology, market structure, and regulation. Previous studies of labour market implications of offshoring have emphasised that the relevant measure of offshoring is narrow offshoring, and most have limited the analysis to manufacturing. However, as services functions gain prominence, the employment effect of narrow offshoring cannot be fully understood if services are ignored. This paper has contributed to filling this gap, but better information and much more research is needed to understand the policy dimension of this phenomenon.

Acknowledgements Open access funding provided by Örebro University. The author gratefully acknowledges financial support from the Norwegian Research Council. Thanks to Sebastian Benz, Holger Breinlich, Bernard Hoekman, Sebastian Miroudot and Lawrence White for useful comments and suggestions; and to Charles Cadestin for assistance with the data.

Open Access This article is licensed under a Creative Commons Attribution 4.0 International License, which permits use, sharing, adaptation, distribution and reproduction in any medium or format, as long as you give appropriate credit to the original author(s) and the source, provide a link to the Creative Commons licence, and indicate if changes were made. The images or other third party material in this article are included in the article's Creative Commons licence, unless indicated otherwise in a credit line to the material. If material is not included in the article's Creative Commons licence and your intended use is not permitted by statutory regulation or exceeds the permitted use, you will need to obtain permission directly from the copyright holder. To view a copy of this licence, visit http://creativecommons.org/licen ses/by/4.0/.

\section{Appendix}

See Tables 7, 8, 9, 10, 11, and 12 . 
Table 7 Descriptive statistics

Panel A controls

\begin{tabular}{llllll}
\hline Variable & Observations & Mean & Standard dev. & Min & Max \\
\hline Length, index & 36,960 & 2.084 & 0.519 & 1 & 9.493 \\
PMR infrastructure, index & 23,925 & 0.254 & 0.374 & 0 & 2.303 \\
Price intermediates index, 2010=100 & 11,610 & 94.6 & 20.5 & 11.9 & 484.5 \\
Capital (USD mill.) & 11,370 & $20,752.9$ & $58,407.3$ & 0.6 & $1,156,994$ \\
ICT maturity & 43 & 0.14 & 0.05 & 0.04 & 0.28 \\
\hline
\end{tabular}

Panel B Business functions

\begin{tabular}{|c|c|c|c|c|c|}
\hline & Observations & Mean & Std. dev & Min & Max \\
\hline \multicolumn{6}{|c|}{ Employment, Thousands } \\
\hline Operations & 10,530 & 109.6 & 377.3 & 0 & $10,195.8$ \\
\hline Transport & 10,530 & 9.7 & 27.2 & 0 & 433.4 \\
\hline Marketing & 10,530 & 7.6 & 23.4 & 0 & 659.4 \\
\hline IT & 10,530 & 1.6 & 6.2 & 0 & 156.0 \\
\hline Management & 10,530 & 16.9 & 53.7 & 0 & 1560.5 \\
\hline$R \& D$ & 10,530 & 7.9 & 20.9 & 0 & 320.1 \\
\hline Other & 10,530 & 10.1 & 26.3 & 0 & 607.3 \\
\hline \multicolumn{6}{|c|}{ Average hourly wages, USD } \\
\hline Operations & 8366 & 18.5 & 18.2 & 0.0 & 537.0 \\
\hline Transport & 7848 & 16.5 & 14.4 & 0.1 & 381.3 \\
\hline Marketing & 7603 & 31.1 & 31.6 & 0 & 748.7 \\
\hline IT & 6219 & 52.3 & 211.4 & 0 & $10,806.4$ \\
\hline Management & 8104 & 25.5 & 21.5 & 0.02 & 387.0 \\
\hline $\mathrm{R} \& \mathrm{D}$ & 7794 & 41.0 & 262.4 & 0 & $19,048.7$ \\
\hline Other & 7993 & 17.5 & 19.3 & 0 & 669.4 \\
\hline \multicolumn{6}{|c|}{ Outsourcing, share of value added } \\
\hline Operations & 11,640 & 0.81 & 0.61 & 0 & 4.91 \\
\hline Transport & 11,640 & 0.08 & 0.07 & 0 & 0.81 \\
\hline Marketing & 11,640 & 0.22 & 0.17 & 0 & 4.50 \\
\hline IT & 11,640 & 0.01 & 0.01 & 0 & 0.16 \\
\hline Management & 11,640 & 0.07 & 0.045 & 0 & 0.73 \\
\hline $\mathrm{R} \& \mathrm{D}$ & 11,640 & 0.02 & 0.03 & 0 & 0.42 \\
\hline Other & 11,640 & 0.03 & 0.03 & 0 & 0.35 \\
\hline \multicolumn{6}{|c|}{ Offshoring, share of value added } \\
\hline Operations & 11,640 & 0.60 & 0.48 & 0 & 7.40 \\
\hline Transport & 11,640 & 0.02 & 0.02 & 0 & 0.32 \\
\hline Marketing & 11,640 & 0.04 & 0.04 & 0 & 0.65 \\
\hline IT & 11,640 & 0.002 & 0.004 & 0 & 0.12 \\
\hline Management & 11,640 & 0.01 & 0.02 & 0 & 0.25 \\
\hline$R \& D$ & 11,640 & 0.004 & 0.01 & 0 & 0.23 \\
\hline Other & 11,640 & 0.01 & 0.04 & 0 & 1.42 \\
\hline
\end{tabular}

ICT maturity is sector-specific and time and country invariant. There are thus 43 unique observations 
Table 8 Weights of the PMR for infrastructure services

Industry

PMR

infrastruc-

ture

\section{C10T12}

0.134

C13T15

0.034

C16

0.028

C17

0.070

C18

0.051

C19

0.460

C20

0.103

C21

0.041

C22

0.071

C23

0.038

C24

0.091

C25

C26

0.166

0.136

$\mathrm{C} 27$

0.041

C28

0.084

C29

0.114

C30

0.073

0.026

C31T32

0.007
Table 9 Baseline regression, aggregate unconditional labour demand

\begin{tabular}{ll}
\hline & Labour demand \\
\hline \multirow{2}{*}{ ln wage } & $-0.183^{* * *}$ \\
$\Delta$ ln capital & $(0.019)$ \\
& $0.113^{* * *}$ \\
$\Delta$ ln price intermediate inputs & $(0.007)$ \\
& $0.067 * * *$ \\
$\Delta$ ln outsourcing & $(0.019)$ \\
& $0.066^{* * *}$ \\
$\Delta$ ln offshoring & $(0.020)$ \\
& -0.022 \\
$\mathrm{R}^{2}$ & $(0.014)$ \\
$\mathrm{N}$ & 0.119 \\
\hline
\end{tabular}

Five-year difference regression. Robust standard errors are reported in parentheses, and $* * *$ represents statistical significance at a $1 \%$ level 
Table 10 Correlation coefficients

\begin{tabular}{llllllll}
\hline & Ln length & Ln Off F1 & Ln Off F2 & Ln Off F3 & Ln Off F4 & Ln Off F5 & Ln Off F6 \\
\hline lnLength & 1 & & & & & & \\
lnOff_F1 & 0.6319 & 1 & & & & & \\
lnOff_F2 & 0.2191 & 0.2985 & 1 & & & & \\
lnOff_F3 & 0.3503 & 0.6158 & 0.4468 & 1 & & 1 & \\
lnOff_F4 & 0.0631 & 0.0466 & 0.1447 & 0.357 & 1 & 1 \\
lnOff_F5 & 0.1211 & 0.0656 & 0.1734 & 0.2809 & 0.3497 & 0.259 & 1 \\
lnOff_F6 & 0.0749 & 0.0654 & 0.0837 & 0.241 & 0.3546 & 0.4547 & 0.3903 \\
lnOff_F7 & 0.101 & 0.1144 & 0.2636 & 0.341 & 0.4978 & 0.45 \\
\hline
\end{tabular}

All correlation coefficients are statistically significant at a $1 \%$ level

Table 11 Unconditional labour demand, narrow offshoring, and length of value chain

\begin{tabular}{|c|c|c|c|c|c|c|c|}
\hline & $\mathrm{F} 1$ & $\mathrm{~F} 2$ & F3 & $\mathrm{F} 4$ & F5 & F6 & F7 \\
\hline Ln wage 1 & $\begin{array}{l}-0.599 * * * \\
(0.041)\end{array}$ & $\begin{array}{l}0.121 * * \\
(0.046)\end{array}$ & $\begin{array}{l}0.121^{*} \\
(0.049)\end{array}$ & $\begin{array}{l}0.023 \\
(0.047)\end{array}$ & $\begin{array}{l}-0.161^{* * *} \\
(0.041)\end{array}$ & $\begin{array}{l}0.020 \\
(0.049)\end{array}$ & $\begin{array}{l}0.080 \\
(0.051)\end{array}$ \\
\hline Ln wage 2 & $\begin{array}{l}-0.079 * * \\
(0.030)\end{array}$ & $\begin{array}{l}-0.565^{* * *} \\
(0.034)\end{array}$ & $\begin{array}{l}-0.125^{* * *} \\
(0.036)\end{array}$ & $\begin{array}{l}-0.106^{* *} \\
(0.034)\end{array}$ & $\begin{array}{l}-0.105^{* * *} \\
(0.030)\end{array}$ & $\begin{array}{l}-0.130^{* * *} \\
(0.036)\end{array}$ & $\begin{array}{l}-0.171 * * * \\
(0.037)\end{array}$ \\
\hline Ln wage 3 & $\begin{array}{l}0.046 * * \\
(0.018)\end{array}$ & $\begin{array}{l}0.096 * * * \\
(0.020)\end{array}$ & $\begin{array}{l}-0.267^{* * *} \\
(0.021)\end{array}$ & $\begin{array}{l}0.074 * * * \\
(0.020)\end{array}$ & $\begin{array}{l}0.084 * * * \\
(0.018)\end{array}$ & $\begin{array}{l}0.112 * * * \\
(0.021)\end{array}$ & $\begin{array}{l}0.080 * * * \\
(0.022)\end{array}$ \\
\hline Ln wage 4 & $\begin{array}{l}0.051 * * \\
(0.017)\end{array}$ & $\begin{array}{l}0.041 * \\
(0.020)\end{array}$ & $\begin{array}{l}-0.006 \\
(0.021)\end{array}$ & $\begin{array}{l}-0.238 * * * \\
(0.020)\end{array}$ & $\begin{array}{l}-0.034 \\
(0.017)\end{array}$ & $\begin{array}{l}-0.046^{*} \\
(0.021)\end{array}$ & $\begin{array}{l}-0.002 \\
(0.022)\end{array}$ \\
\hline Ln wage 5 & $\begin{array}{l}-0.110^{* * *} \\
(0.029)\end{array}$ & $\begin{array}{l}0.021 \\
(0.033)\end{array}$ & $\begin{array}{l}0.015 \\
(0.035)\end{array}$ & $\begin{array}{l}0.115^{* * *} \\
(0.033)\end{array}$ & $\begin{array}{l}-0.141^{* * *} \\
(0.029)\end{array}$ & $\begin{array}{l}0.110^{* *} \\
(0.035)\end{array}$ & $\begin{array}{l}-0.078 * \\
(0.036)\end{array}$ \\
\hline Ln wage 6 & $\begin{array}{l}0.061 * * * \\
(0.016)\end{array}$ & $\begin{array}{l}-0.029 \\
(0.018)\end{array}$ & $\begin{array}{l}0.040 * \\
(0.019)\end{array}$ & $\begin{array}{l}0.022 \\
(0.018)\end{array}$ & $\begin{array}{l}-0.086^{* * *} \\
(0.016)\end{array}$ & $\begin{array}{l}-0.414^{* * * *} \\
(0.020)\end{array}$ & $\begin{array}{l}0.072 * * * \\
(0.020)\end{array}$ \\
\hline Ln wage 7 & $\begin{array}{l}-0.074 * * \\
(0.026)\end{array}$ & $\begin{array}{l}-0.085^{* *} \\
(0.029)\end{array}$ & $\begin{array}{l}-0.126^{* * *} \\
(0.031)\end{array}$ & $\begin{array}{l}-0.028 \\
(0.030)\end{array}$ & $\begin{array}{l}-0.052^{*} \\
(0.026)\end{array}$ & $\begin{array}{l}-0.023 \\
(0.031)\end{array}$ & $\begin{array}{l}-0.499 * * * \\
(0.032)\end{array}$ \\
\hline $\begin{array}{l}\text { Ln price inter- } \\
\text { mediates }\end{array}$ & $\begin{array}{l}-0.055 \\
(0.033)\end{array}$ & $\begin{array}{l}-0.015 \\
(0.037)\end{array}$ & $\begin{array}{l}-0.191^{* * *} \\
(0.039)\end{array}$ & $\begin{array}{l}-0.057 \\
(0.037)\end{array}$ & $\begin{array}{l}0.008 \\
(0.033)\end{array}$ & $\begin{array}{l}-0.009 \\
(0.039)\end{array}$ & $\begin{array}{l}0.298 * * * \\
(0.041)\end{array}$ \\
\hline Ln capital & $\begin{array}{l}0.485 * * * \\
(0.007)\end{array}$ & $\begin{array}{l}0.312 * * * \\
(0.008)\end{array}$ & $\begin{array}{l}0.265^{* * *} \\
(0.009)\end{array}$ & $\begin{array}{l}0.277 * * * \\
(0.008)\end{array}$ & $\begin{array}{l}0.365^{* * *} \\
(0.007)\end{array}$ & $\begin{array}{l}0.398 * * * \\
(0.009)\end{array}$ & $\begin{array}{l}0.359 * * * \\
(0.009)\end{array}$ \\
\hline Ln outsourcing & $\begin{array}{l}-0.017 \\
(0.042)\end{array}$ & $\begin{array}{l}-0.754 * * * \\
(0.127)\end{array}$ & $\begin{array}{l}0.165^{*} \\
(0.072)\end{array}$ & $\begin{array}{l}-2.589 * * * \\
(0.778)\end{array}$ & $\begin{array}{l}0.295 \\
(0.160)\end{array}$ & $\begin{array}{l}0.940 * * * \\
(0.249)\end{array}$ & $\begin{array}{l}0.622 * \\
(0.279)\end{array}$ \\
\hline $\begin{array}{l}\text { Ln offshoring } \\
\text { (narrow) }\end{array}$ & $\begin{array}{l}-0.735^{* * *} \\
(0.186)\end{array}$ & $\begin{array}{l}-9.772 * * * \\
(2.315)\end{array}$ & $\begin{array}{l}-6.782^{* * * *} \\
(1.376)\end{array}$ & $\begin{array}{l}41.708 * * \\
(14.757)\end{array}$ & $\begin{array}{l}-17.793^{* * *} \\
(3.093)\end{array}$ & $\begin{array}{l}10.091 * \\
(4.141)\end{array}$ & $\begin{array}{l}-0.413 \\
(0.885)\end{array}$ \\
\hline Ln Length & $\begin{array}{l}-0.168 \\
(0.123)\end{array}$ & $\begin{array}{l}-0.012 \\
(0.090)\end{array}$ & $\begin{array}{l}-0.866^{* * * *} \\
(0.101)\end{array}$ & $\begin{array}{l}0.076 \\
(0.090)\end{array}$ & $\begin{array}{l}-0.462^{* * * *} \\
(0.079)\end{array}$ & $\begin{array}{l}-0.225^{*} \\
(0.091)\end{array}$ & $\begin{array}{l}-0.180 \\
(0.094)\end{array}$ \\
\hline $\begin{array}{l}\text { Ln } \\
\text { offshoring*ln } \\
\text { length }\end{array}$ & $\begin{array}{l}0.937 * * * \\
(0.153)\end{array}$ & $\begin{array}{l}10.401^{* * *} \\
(2.326)\end{array}$ & $\begin{array}{l}7.543 * * * \\
(1.319)\end{array}$ & $\begin{array}{l}-41.534 * * \\
(14.896)\end{array}$ & $\begin{array}{l}19.613^{* * *} \\
(2.937)\end{array}$ & $\begin{array}{l}-12.706^{* *} \\
(4.746)\end{array}$ & $\begin{array}{l}0.838 \\
(0.925)\end{array}$ \\
\hline $\mathrm{R}^{2}$ & 0.939 & 0.905 & 0.879 & 0.761 & 0.920 & 0.856 & 0.877 \\
\hline $\mathrm{N}$ & 5887 & 5887 & 5887 & 5887 & 5887 & 5887 & 5887 \\
\hline
\end{tabular}

Seemingly unrelated regressions for each business function, using country, year, and sector fixed effects. Standard errors in parentheses and ***,**, and * signify statistical significance at a $1 \%, 5 \%$, and $10 \%$ level, respectively 


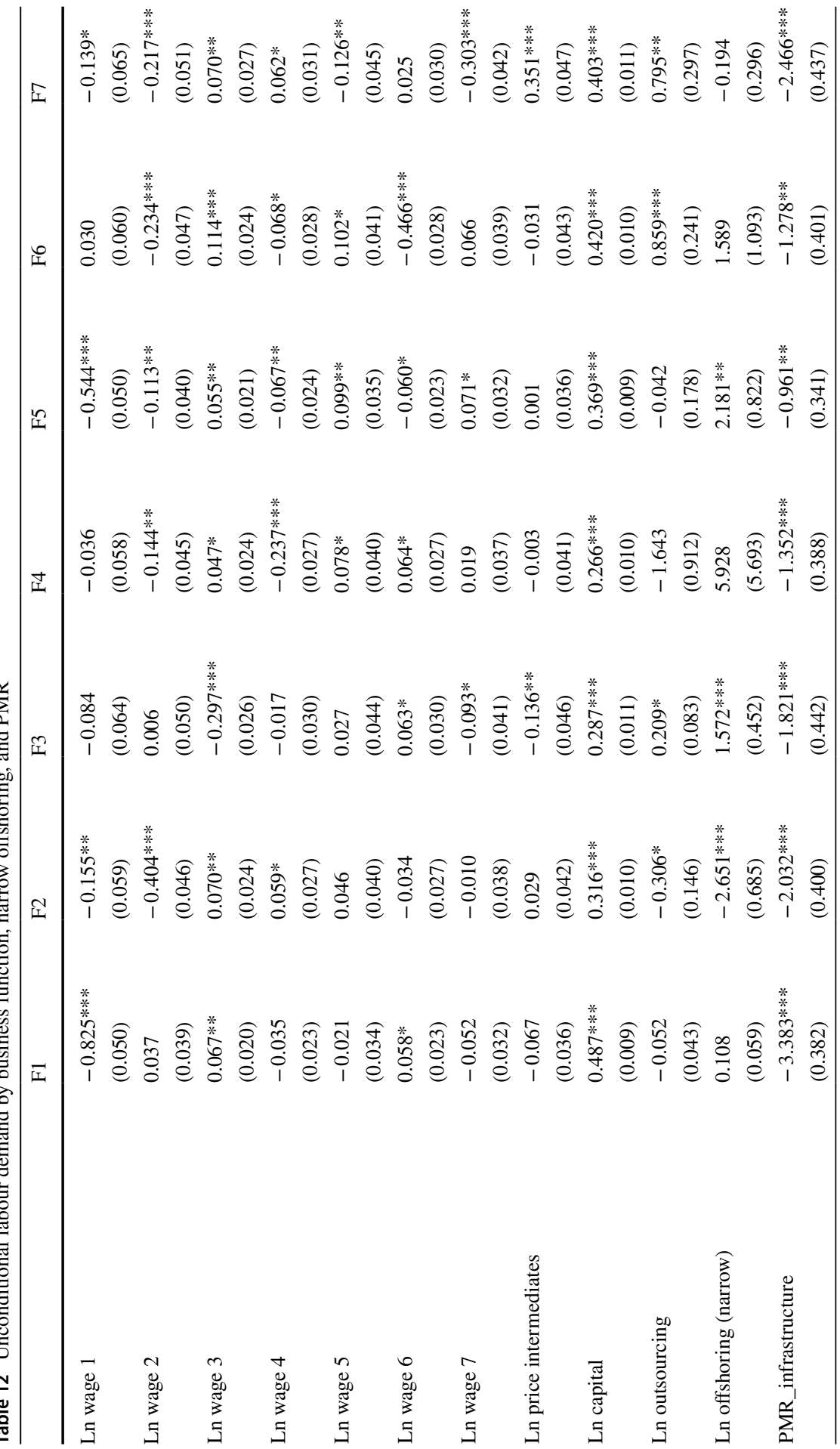




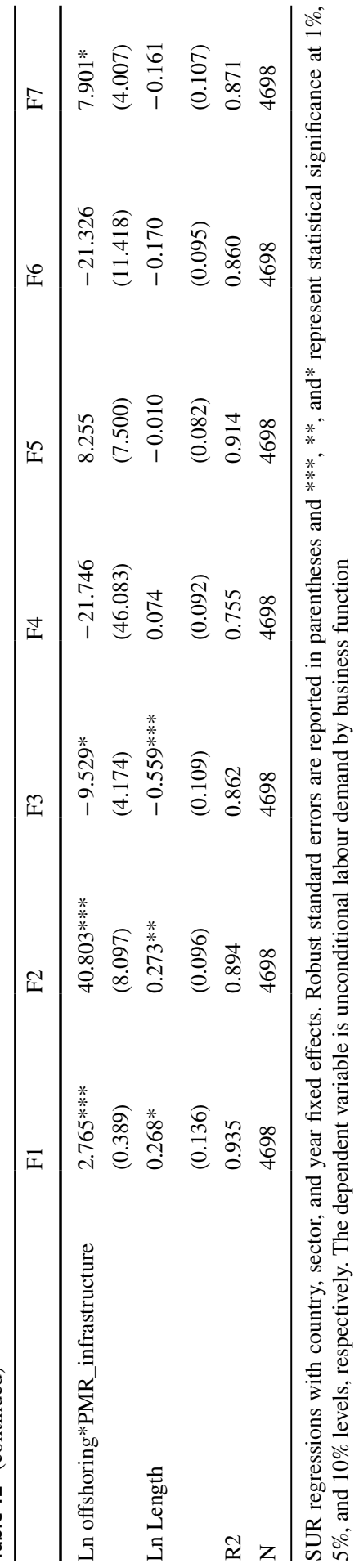


The PMR for infrastructure services covers transport, electricity, post, and telecommunications. The weights to obtain sector-specific PMRs for each WIOD manufacturing sector is derived from the sum of the coefficient for transport, electricity, gas, post, and telecommunications in the inverse Leontief matrix for the United States in the year 2000. These weights reflect the direct and indirect importance of infrastructure services in each sector. The weights from the US inverse Leontief matrix in the first year of the analysis is used to mitigate possible endogeneity problems.

\section{References}

Acemoglu, D., \& Restrepo, P. (2018). The race between man and machine: Implications of technology for growth, factor shares and employment. The American Economic Review, 108(6), 1488-1542.

Antràs, P., \& Helpman, E. (2004). Global sourcing. Journal of Political Economy, 112(3), 552-580. https ://doi.org/10.1086/383099.

Bashir, H., \& Thomson, V. (1999). Estimating design complexity. Journal of Engineering Design, 10(3), 247-257. https://doi.org/10.1080/095448299261317.

Bengtsson, L., \& Dabhilkar, M. (2009). Manufacturing outsourcing and its effect on plant performanceLessons for KIBS outsourcing. Journal of Evolutionary Economics. https://doi.org/10.1007/s0019 1-008-0129-1.

Calvino, F., Criscuolo, C., Marcolin, L., \& Squicciarini, M. (2018). A taxonomy of digital intensive sectors. OECD Science, Technology and Industry Working Papers No. 2018/14. Paris: OECD Publishing. https://dx.doi.org/10.1787/f404736a-en.

De Backer, K., \& Miroudot, S. (2013). Mapping global value chains. OECD Trade Policy Papers No. 2013/159. Paris: OECD Publishing. http://dx.doi.org/10.1787/5k3v1trgnbr4-en.

Elia, S., Massini, S., \& Narula, R. (2017). Disintegration, modularity and entry mode choice: Mirroring technical and organizational architectures in business functions offshoring. Journal of Business Research, 103, 417-431.

Foster-McGregor, N., Poeschl, J., \& Stehrer, R. (2016). Offshoring and the elasticity of labour demand. Open Economies Review, 27(3), 515-540. https://doi.org/10.1007/s11079-015-9384-6.

Foster-McGregor, N., Stehrer, R., \& de Vries, G. (2013). Offshoring and the skill structure of labour demand. Review of World Economics, 149(4), 631-662. https://doi.org/10.1007/s10290-013-0163-4.

Geishecker, I., \& Görgy, H. (2013). Services offshoring and wages: Evidence from micro data. Oxford Economic Papers, 65(1), 124-146. https://doi.org/10.1093/oep/gpr055.

Grossman, G., \& Rossi-Hansberg, E. (2008). Trading tasks: A simple theory of offshoring. American Economic Review, 98(5), 1978-1997. https://doi.org/10.1257/aer.98.5.1978.

Hijzen, A., Görg, H., \& Hine, R. (2005). International outsourcing and the skill structure of labour demand in the United Kingdom. The Economic Journal, 115(506), 860-878. https://doi.org/10.111 1/j.1468-0297.2005.01022.x.

Hijzen, A., Pisu, M., Upward, R., \& Wright, P. W. (2011). Employment job turnover and trade in producer services: UK firm-level evidence. Canadian Journal of Economics, 44(3), 1020-1043. https:// doi.org/10.1111/j.1540-5982.2011.01664.x.

Hijzen, A., \& Swaim, P. (2010). Offshoring, labour market institutions and the elasticity of labour demand. European Economic Review, 54(8), 1016-1034. https://doi.org/10.1016/j.euroecorev .2010.04.001.

Koske, I., Wanner, I., Bitetti, R., \& Barbiero, O. (2015). The 2013 update of the OECD's database on product market regulation: Policy insights for OECD and non-OECD countries. OECD Economics Department Working Papers No. 1200. Paris: OECD Publishing. https://dx.doi.org/10.1787/5js3f $5 \mathrm{~d} 3 \mathrm{n} 2 \mathrm{vl}-\mathrm{en}$.

Liu, R., \& Trefler, D. (2008). Much ado about nothing: American jobs and the rise of service outsourcing to China and India. NBER Working Paper No. 14061. http://dx.doi.org/10.3386/w14061.

Melitz, M. (2003). The impact of trade on intra-industry reallocations and aggregate industry productivity. Econometrica, 71(6), 1695-1725. https://doi.org/10.1111/1468-0262.00467. 
Miroudot, S., \& Cadestin, C. (2017). Services in global value chains: From inputs to value-creating activities. OECD Trade Policy Papers. No. 197. Paris: OECD Publishing. http://dx.doi.org/10.1787/465f0 d8b-en.

Muller, E., \& Zenker, A. (2001). Business services as actors of knowledge transformation: The role of KIBS in regional and national innovation systems. Research Policy, 30(9), 1501-1516.

Nordås, H. (2019). Offshoring of services functions and labour market adjustments. OECD Trade Policy Paper No. 226. Paris: OECD Publishing. https://doi.org/10.1787/1590079f-en.

Nordås, H., \& Rouzet, D. (2017). The impact of services trade restrictiveness on trade flows. World Economy, 40(6), 1155-1183. https://doi.org/10.1111/twec.12424.

Novak, S., \& Eppinger, S. (2001). Sourcing by design: Product complexity and the supply chain. Management Science, 47(1), 189-204. https://doi.org/10.1287/mnsc.47.1.189.10662.

Porter, M. (1979). How competitive forces shape strategy. Harvard Business Review. https://doi. org/10.1097/00006534-199804050-00042.

Stigler, G. (1951). The division of labor is limited by the extent of the market. Journal of Political Economy, 59(3), 184-193. https://doi.org/10.1086/257075.

Tadelis, S. (2002). Complexity, flexibility, and the make-or-buy decision. American Economic Review, 92(2), 433-437. https://doi.org/10.1257/000282802320191750.

Timmer, M., Dietzenbacher, E., Los, B., Stehrer, R., \& de Vries, G. (2015). An illustrated user guide to the world input-output database: The case of global automotive production. Review of International Economics, 23(3), 575-605. https://doi.org/10.1111/roie.12178.

Walker, G., \& Weber, D. (1984). A transaction cost approach to make-or-buy decisions. Administrative Science Quarterly, 29, 373-391.

Williamson, O. (1981). The economics of organization: The transaction cost approach. American Journal of Sociology, 87(3), 548-577.

Wright, G. (2014). Revisiting the employment impact of offshoring. European Economic Review, 66, 63-83. https://doi.org/10.1016/j.euroecorev.2013.11.008.

Publisher's Note Springer Nature remains neutral with regard to jurisdictional claims in published maps and institutional affiliations. 